\title{
Financial Derivatives: The Concepts, Operations, and Impact on the Nigerian Economy
}

\author{
Fadimatu Jalal-Eddeen ${ }^{1}$, Zainab J. Saleh ${ }^{2}$ \\ ${ }^{1}$ School of Social and Management Sciences, Department of Cooperative Economics, Adamawa State Polytechnic, Jimeta-Yola, \\ Nigeria \\ ${ }^{2}$ School of Science and Technology, Middlesex University, Malta, Pembroke, Malta \\ Email: ^fadjals@gmail.com
}

How to cite this paper: Jalal-Eddeen, $\mathrm{F}$. and Saleh, Z.J. (2022) Financial Derivatives: The Concepts, Operations, and Impact on the Nigerian Economy. Open Access Library Journal, 9: e8102.

https://doi.org/10.4236/oalib.1108102

Received: October 20, 2021

Accepted: January 16, 2022

Published: January 19, 2022

Copyright $\odot 2022$ by author(s) and Open Access Library Inc.

This work is licensed under the Creative Commons Attribution International License (CC BY 4.0).

http://creativecommons.org/licenses/by/4.0/

(c) (i) Open Access

\begin{abstract}
Background: In an economic sense, derivatives are often used for commodities, including oil, gasoline, silver, gold, iron ore, currencies, stocks, and bonds. The derivative is considered as a financial contract that derives its value from an underlying asset. The buyer of the asset agrees to purchase it on a specific date and at a particular price. In the past couple of decades, financial derivatives evolved, and this is not unrelated to the fundamental changes in the financial markets across the globe. Methods: This systematic review visited various relevant sites and synthesised literature from relevant publications. The write-up discussed the growth of financial derivatives, especially in the past two decades, the innovations in financial theory, changes in the foreign markets, and increased computerisation. Results: The outcome of this review has shown that since the inception of financial derivatives in the early 1970s, there are various instruments that have evolved and are considered critical. Some of these instruments include futures contracts, forward markets, options, swaps, and hybrids. Conclusion: Undeniably, the complexities of the derivatives market keep increasing and on a daily basis; the Nigerian economy is not an exception or spared. This review is critical and timely, hence the need for government officials, policymakers, financial regulators, and academia to effectively understand this fluidity in the global financial markets. Given the fluidity of the global economies and evolving nature of financial transactions in the global space, this write-up would help in sensitizing help policymakers and financial regulators when adopting significant legislative or regulatory changes regarding the country's financial dealings in the global space.
\end{abstract}

\section{Subject Areas}

Business Analysis 


\section{Keywords}

Financial Derivatives, Economy, Financial Markets, Futures Contracts, Forward Markets, Options, Swaps, Hybrids, Africa, and Nigeria

\section{Introduction}

Globally, Nigeria is considered a middle-income, mixed economy as it is among the top emerging markets, especially as the economy keeps expanding in the manufacturing, financial, communications, information technology, and entertainment sectors [1] [2] [3]. While the country is ranked as the $27^{\text {th }}$-largest economy globally in terms of nominal GDP, Nigeria takes the $24^{\text {th }}$ position in purchasing power parity. On the African continent, Nigeria's GDP stands at 514 billion U.S. dollars in 2021, topping the list of leading economies on the continent, trailed by Egypt, with a GDP of about 394 billion U.S. dollars [1] [2] [3]. This review looks at the concept of financial derivative, how it is operationalized and its impact on the Nigerian economy. Amadeo (2021) observed that a derivative is considered a financial contract that derives its value from an underlying asset [4]. The term "derivative" as defined by International Monetary Fund (IMF) is a financial instrument linked to a specific financial instrument, indicator, or commodity. Specific financial risks can be traded in financial markets [5] [6]. Within the context of this definition, the buyer of the asset has an agreement with the other party to purchase an asset on a specific date and at a specific price. Similarly, and in an economic sense, the derivatives include but are not limited to commodities, such as oil, gas, silver, gold, iron ore, international currencies, predominantly the U.S. dollar, stocks, and bonds [4]. The other derivatives use interest rates, such as the Treasury Bond, yield over a stipulated time, for example, five years. In some circumstances, however, the seller of the contract doesn't necessarily have to own the underlying asset under consideration and can fulfil the contract by giving the buyer adequate money to buy the asset at a prevailing price. Additionally, and in simplifying the processes, there are instances where the seller could provide the buyer with another derivative contract to offset the value of the initial contract. In the context of this review, and having defined what derivatives are, it is critical to look at what financial derivatives mean [4] [5] [6].

Osayi et al. (2018) stated that financial derivatives could be defined as financial instruments linked to a specific financial instrument or commodity, through which specific financial risk can be traded in the financial market [7]. Thus, there is a need for financial derivatives to be treated as separate transactions rather than an integral part of the value of the underlying transaction to which they are linked. Additionally, financial derivatives are also used for other purposes such as risk management, hedging, arbitrage between markets and speculation. Osayi et al. (2018) observed that it is equally critical to underscore that 
financial market derivatives help reduce risks, thus allowing for greater fiscal autonomy and political sovereignty. Some firms also use derivatives to reduce their financial distress risk, and this distress risk has a system component that is priced in the market [7]. The next section of this paper intends to look at the history/evolution of financial derivatives.

\section{Evolution of Financial Derivatives}

The evolution of financial derivatives during the past two decades is related to the fundamental changes in the financial markets [8]. As observed by Sangha, (1995), the $21^{\text {st }}$ century has brought innovations in financial theory and increased computerization [8]. These improvements came along with changes in the foreign exchange markets, the credit markets, and the capital markets over the period. It has also contributed to the growth of financial derivatives. The record shows that the first exchange-traded financial derivatives came into existence after the collapse of the Bretton Woods system of exchange rates that was established in 1944. However, this development resulted in most governments agreeing to fix the exchange rate of their currencies relative to the U.S. dollar, and this could be converted into gold. Similarly, in 1971, the U.S. Treasury abandoned the gold standard for the dollar, causing the breakdown of the fixed-exchange system, which was replaced by a floating-rate exchange system [8].

According to Sangha (1995), what brought an impetus for emerging currency futures was the need to hedge against adverse exchange-rate movements provided an impetus. It was observed that foreign currency futures were introduced at the Chicago Mercantile Exchange in 1972. Similarly, 1973 heralded the creation of the Chicago Board Options Exchange (CBOE) by the Chicago Board of Trade (CBOT) to facilitate the trade of options on selected stocks [8]. In the mid-1970s, futures contracts on interest-bearing government securities were introduced. The Federal Reserve Board, in October 1979, abandoned its earlier policy of setting interest rate targets, replacing it with money supply targets. However, the shift in Federal Reserve policy increased the interest-rate volatility of Treasury bonds [8]. The increase in volatility invigorated the demand for derivatives to hedge against adverse interest rate movements.

The groundwork for new portfolio management techniques came into being because of the advancement in options pricing research along with improvements in computer technology laid [8]. It is critical to underscore that these portfolio management techniques require a futures proxy for equities that could be sold to hedge against a downswing in stock prices. Similarly, the needs of portfolio managers through the introduction of futures contracts on equity indexes in the early 1980s were responded to by the Chicago Board Mercantile Exchange and the CBOE. However, it is significant to note that the increasing globalization of commerce has exposed firms to various financial risks, which are often unrelated to their lines of business. Sangha (1995) observed that some 
of these risks are firm or situation-specific with no ready-made exchange-traded instruments to offset such risks [8]. Again, a new line of financial derivatives, the over-the-counter (OTC) derivatives, has created the management of these risks. It is significant to note that these derivatives are privately negotiated arrangements between parties, permitting either one or all parties to obtain their desired financial flows. Finally, the OTC derivatives have grown faster than the exchange-traded contracts in recent years [8].

\section{Common Derivatives Instruments}

Sangha (1995) observed that the financial derivative instruments had quickly increased from simple financial futures to a wide variety of exotic and complicated securities beginning from their early days in the 1970s [8]. According to Sangha (1995), some of these financial derivatives include futures contracts, forward markets, options, swaps, and other derivatives instruments:

\subsection{Futures Contracts}

The exchanges trade standard contracts on specific financial securities of specified amounts to be delivered at a designated time [8]. Notably, these are traded exclusively at organized exchanges. Similarly, private parties enter a contract with a central clearinghouse, becoming the opposite party to the transaction. Thus, in such situations, the clearinghouse brings together parties seeking to take opposing positions [8]. However, the risk of default by a party is low because the clearinghouse is the opposite party, and the clearinghouse uses daily mark-to-market settlement rules to reduce its risk exposure. It is critical to highlight that some of the most popular financial contracts include futures on Eurodollars, treasury securities, certificates of deposit, municipal bond indexes, S\&P 500 index, and New York Stock Exchange composite index.

\subsection{Forward Markets}

These, unlike the futures markets that offer standardized exchange-traded contracts with a specific amount and delivery dates, consist of contracts that are custom-made and privately negotiated between parties. These are considered an extension of spot or cash markets for deferred delivery of a commodity. In the $90 \mathrm{~s}$, the financial forwards market comprises 42 per cent of the global derivatives market [8]. However, foreign exchange contracts dominate the market for forwarding contracts. In the $21^{\text {st }}$ century, the derivatives market, on the high end, is estimated at over $\$ 1$ quadrillion, and this is large because there are numerous derivatives in existence.

Similarly, this is available on various investment assets, such as equities, commodities, bonds, and currency. Again, other market analysts view the market size at more than ten times the total global gross domestic product (GDP). Nonetheless, other researchers challenge the derivatives market estimates on the premise that the size is overstated [9]. 


\subsection{Options}

The options differ from both futures and forward contracts because a party to the options contract exercises its right only if the underlying asset's value reaches a specific amount, which is called the strike price. Thus, a payoff from purchasing an option occurs only when the price drops or rises to the specific strike price, which depends on the type of the options contract. Similarly, options are traded OTC at an organized exchange. The options can be written on individual equities, equity indexes, interest-rate instruments, and currency values. It is important to mention that the initial pioneering research on options was directed primarily at pricing equity options, including Black and Scholes's seminal work (1973). But, over time, the use of interest-rate derivatives has come to dominate the equity and currency options [8] [9].

\subsection{Swaps}

Depending on the terms of the contract, the swaps, the periodic payments could be a fixed amount, or a variable (floating) amount based on either one or some combination of foreign exchange rates, interest rates, equity indexes, or commodity prices. They are considered privately negotiated contracts between two parties are stipulating the exchange of cash payments determined by the price of the underlying asset or the difference in the returns to different assets. Notably, entering a swap contract means that parties can exchange their existing payment patterns for their desired payment streams. Still, it should be underscored that a swap agreement can extend up to ten years [8] [9].

\subsection{Other Derivatives Instruments}

The listed derivative instruments above constitute the building blocks for creating a more complex array of custom-made and situation-specific derivative instruments. There is a need to mention that other financial products that have witnessed growth in recent years also include the "hybrids." The hybrids are considered instruments that have characteristics of more than one type of financial instrument. However, the list of complex derivatives is vast because innovative and creative financial strategists have continued to develop new products, and these are tailor made for each application. I have presented below, in a tabular form (Table 1), some examples of complex instruments [8] [9] [10].

\section{Operations}

According to Sangha (1995), to operationalize derivatives, it has been observed that businesses, individuals, and governments all use them to accomplish a wide variety of objectives [8]. These instruments are often used by businesses to manage their risk exposure and lower their financing costs. Similarly, derivatives play a very significant and critical role in integrating world capital and production markets. The following are the major functions of derivatives: 
Table 1. Examples of complex instruments.

\begin{tabular}{|c|c|}
\hline Name & Description \\
\hline Generic swap & $\begin{array}{l}\text { Is the most basic swap, which transforms floating rate interest payments } \\
\text { into fixed rate payments for one party, and vice versa for the } \\
\text { counterparty to the contract. }\end{array}$ \\
\hline Swaption & $\begin{array}{l}\text { It is a type of contract that gives the holder a right to buy or sell a swap, } \\
\text { i.e., an option to exchange cash flows. }\end{array}$ \\
\hline $\begin{array}{l}\text { Basis index } \\
\text { swap }\end{array}$ & $\begin{array}{l}\text { It is an agreement to exchange the interest payments based on different } \\
\text { indexes and used by counterparties to reduce their risk exposure } \\
\text { resulting from a nonlinear movement in interest rates across two } \\
\text { different indexes. }\end{array}$ \\
\hline $\begin{array}{l}\text { Yield curve } \\
\text { swap }\end{array}$ & $\begin{array}{l}\text { It is a contract to exchange interest payments indexed to a long-term rate } \\
\text { with those indexed to a short-term rate for one party, and vice versa for } \\
\text { the counterparty. }\end{array}$ \\
\hline $\begin{array}{l}\text { Forward Rate } \\
\text { Agreement } \\
\text { (FRA) }\end{array}$ & $\begin{array}{l}\text { It is an extension of a forward contract except that, unlike the single } \\
\text { payment feature of forward contracts, an FRA can incorporate multiple } \\
\text { periodic payments. }\end{array}$ \\
\hline Cap & $\begin{array}{l}\text { It is an agreement that permits the buyer to receive the difference in the } \\
\text { interest cost on a specified notional amount if the interest rate rises above } \\
\text { the stipulated "cap rate." }\end{array}$ \\
\hline Collar & $\begin{array}{l}\text { It is a combination of a cap and floor agreement, in which the buyer } \\
\text { purchases an interest rate cap while selling a floor indexed to the same } \\
\text { interest rate. The name "collar," is because they have the effect of limiting } \\
\text { the effective borrowing rate between the cap rate and the floor rate. }\end{array}$ \\
\hline Nonpar swap & $\begin{array}{l}\text { The interest rates used in a nonpar swap are different than the market } \\
\text { interest rates for par-value bonds. It is different from most other swaps. } \\
\text { Thus, one party may be required to make a payment at contract } \\
\text { initiation. The nonpar swaps are typically used to offset existing par swap } \\
\text { positions, the underlying interest rates for which may have changed since } \\
\text { their inception. }\end{array}$ \\
\hline $\begin{array}{l}\text { Zero coupon } \\
\text { swaps }\end{array}$ & $\begin{array}{l}\text { It is an agreement where one counterparty makes only one payment at } \\
\text { the termination of the swap, analogous to a zero-coupon bond. The other } \\
\text { party makes periodic fixed or floating rate payments. }\end{array}$ \\
\hline Floor & $\begin{array}{l}\text { It is analogous to a cap, except that a payment is triggered by interest } \\
\text { rates falling below a specified threshold. }\end{array}$ \\
\hline Caption & $\begin{array}{l}\text { It is a contract that gives the holder a right to buy a cap should the } \\
\text { stipulated conditions be met. }\end{array}$ \\
\hline
\end{tabular}

\subsection{Risk Management}

Risk management is considered an essential tool of the futures markets and the driving force behind the development of financial futures contracts during the early 1970s. It has been shown that traders use currency futures to protect (hedge) themselves against fluctuations in exchange rates because this may be detrimental to their profit margins. Similarly, a trader in the U.S. who requires foreign currency for a business transaction over six months could sell a futures foreign 
currency contract for the same amount maturing in six months. However, if after a period of six months, the U.S. dollar depreciated relative to the foreign currency, this would attract some losses in the spot market, though gains from the futures contract can exactly offset it. Conversely, if the dollar appreciated relative to the foreign currency, the trader would sustain losses in the futures market, offsetting the gains in the spot market. Therefore, in a typical hedge, the gains/ losses from derivative and spot markets tend to offset each other. Consequently, examining derivatives-related losses (gains) from hedging in isolation of the spot market gains (losses) is not meaningful; that is why sometimes this element of hedging transactions highlights derivatives-related losses [8].

\subsection{Lowering Financing Cost}

Businesses, to reduce financial costs, adopt the use of derivatives. Using derivative products, businesses can enhance a firm's ability to reduce its cost of debt, and this could be through the following mechanisms [8]:

1) Obtaining better financing terms from lenders by reducing the risk of its venture by engaging in hedging activities.

2) Capitalizing on differences in interest rates across borders and maturities. Business firms could issue debt in a country with lower interest rates. However, using currency swaps, a business can protect itself against foreign exchange risk.

3) Benefitting from "quality spread" arising due to differences in interest-rate spreads between fixed- and adjustable-rate credit markets. Usually, the quality spread between firms from two extreme ends of credit ratings is larger in the fixed-rate market than the adjustable-rate market.

Similarly, and as observed by Sangha (1995), it is also possible to reduce financing costs by using interest-rate swaps and swaptions to transform callable, puttable, floating, and nonconventional debt to other forms of debt. Additionally, as stated by Sangha (1995), businesses could use derivatives to take advantage of low-interest rates to lock in the financing costs of a future debt issue [8].

\subsection{Asset Management}

In asset management, derivative instruments play an essential role. A critical reason for this is the low transaction costs associated with acquiring derivative instruments relative to the spot market instruments. An example shows that a futures contract can replicate the payoff stream from holding all equities in the S \& P 500 list on the S \& P 500 index at a fraction of the cost of acquiring all 500 equities [8].

\subsection{Completing the Market for Investors}

It has also been observed that derivatives provide investment opportunities unavailable at organized exchanges [8]. It is significant to note that derivatives offer investors a means to venture into unfamiliar equity markets around the globe at lower cost and risk than the traditional means. Similarly, it was observed that OTC derivatives tailored to meet the needs of specific business situations also 
extend the investment and capital formation opportunities beyond those offered in equity markets.

\subsection{Tax or Regulatory Advantage}

Derivatives provide firms tax planning opportunities by taking advantage of asymmetries in the tax and the regulatory requirements across different countries, markets, or securities. It can be used to issue debt in tax-favoured jurisdictions or through a tax-favoured instrument to replicate the payment stream of a high taxed jurisdiction or security. Similarly, derivatives may be used by some regulated industries to reduce the impact of certain regulatory restrictions and limitations [8].

\subsection{Speculation}

In speculating on the price of interest-bearing security, on the value of equity indexes, and foreign exchange prices, derivatives also play a critical role in that regard. It is critical to note that speculators get motivated by the gains from their speculative positions and the risk premium they charge for providing hedging services [8].

Given the above discourse, it is important to underscore derivatives provide a useful function by reducing price uncertainty; this on the overall has a positive impact on the overall economy because the production levels are higher under certain prices relative to uncertain market prices. Similarly, derivatives facilitate global commerce by providing firms with the ability to reduce their foreign exchange risk, their cost of obtaining funds and the risk and transactions costs of investing in foreign equity markets.

\section{Impact of Derivatives on the Nigerian Economy}

Osuaha (2013) noted that the growth of financial markets, particularly the derivatives market, would go a long way to enhance the effectiveness of monetary policy in Nigeria, thus helping speed up transmission processes by influencing expectations, thus adding power or credibility the process [11]. This argument is based on the finding by Vrolijk (1997) that the greater use of derivatives can speed up the transmission of monetary policy from short-term interest rates that are more sensitive to monetary policy developments [12]. Thus, the greater use of derivatives would help the financial market reaction to monetary policy be less abrupt as they are designed to help insulate first at level temporarily from unexpected changes in revenue and debt servicing cost [11] [12].

In the same vein, Osuoha (2010) identified other advantages that the derivatives market can bring to the Nigerian economy to include lower transaction costs, better liquidity, faster and easier transaction, and the possibility of short selling. He further adds that achieving greater leverage, deepening of the market, and the possibility of investing in a whole basket of stock through the stock index as other advantages [13]. 
In his empirical investigation of 18 Nigerian banks on the use of interest rate derivatives, Osuaha (2010) suggested that a potential benefit of derivatives usage is its ability to allow an organization to maintain a smooth operating policy in the event of external shocks as falling oil prices [13]. Reflecting on the Nigerian case, Osuaha (2010) noted that interest rate risk has a significant impact on the banking sector, and that provides a useful setting to test the theories of risk management. His findings show that the derivatives non-user banks' lending volume declines significantly with a concentration in the money supply. Still, Nigerian derivatives users remain immune to the monetary policy shocks.

It was also found by Delechat et al. (2010) that the degree of financial market development is a crucial determinant of the distribution of capital flow across countries like Nigeria. The authors established a strong positive correlation between private capital inflows and real GDP growth in recipient countries [5]. They noted that the more developed the capital market, the higher the capital inflow. However, in the case of Nigerian, this implies that a better derivatives market will lead to more capital inflow for development. Delechat et al. (2010) noted that the global financial crises and recession have led to a decline of private capital flows to all world regions [5]. The authors concluded that policymakers in Nigeria would need to pay increasing attention to efforts to attract private capital to their countries by strengthening the domestic capital markets and, more specifically, the derivatives market [5].

\section{Conclusion}

Given that Nigeria is among the top evolving economies globally, this review is critical to remind government officials, policymakers, and those in academia about financial derivatives and the evolving changes in the global economy. The review was able to discuss that financial derivatives have proliferated in recent years. It was noted that growth is linked to improvements in computer technology, innovations in financial theory, and the need to manage risks arising from volatility in the interest and currency exchange rates. The review further underscores derivatives are increasingly being used to manage various kinds of risk exposure, obtain desirable financing, and enhance investment and speculative opportunities. However, the complexities of the derivatives markets are increasing every day, hence the need for Nigerian policymakers and regulators to understand these markets before they hastily adopt any major legislative or regulatory changes. Most importantly, as this paper has shown, financial derivatives can have a significant impact on the Nigerian economy.

\section{Conflicts of Interest}

The authors declare no conflicts of interest.

\section{References}

[1] The World Bank (2021) Nigeria. https://data.worldbank.org/country/nigeria 
[2] USAID (2021) Economic Growth and Trade. Nigeria. https://www.usaid.gov/nigeria/economic-growth

[3] Statista (2021) African Countries with the Highest Gross Domestic Product (GDP) in 2021.

https://www.statista.com/statistics/1120999/gdp-of-african-countries-by-country/

[4] Amadeo, K. (2021) Financial Derivatives: Definition, Types, Risks. https://www.thebalance.com/what-are-derivatives-3305833

[5] Deléchat, C., Ramirez, G., Wagh, S. and Wakeman-Linn, J. (2010) How Global Financial Markets Affect Sub-Saharan Africa. IMF Staff Papers, 57, 172-208.

https://doi.org/10.1057/imfsp.2009.29

[6] International Monetary Fund (1998) Financial Derivatives. Eleventh Meeting of the IMF Committee on Balance of Payments Statistics. https://www.imf.org/external/pubs/ft/bop/1998/bopcmt98.pdf

[7] Sangha, B.S. (1995) Financial Derivatives: Applications and Policy Issues. Business Economics, 30, 46-52. http://www.jstor.org/stable/23486114

[8] Maverick, J.B. (2020) How Big Is the Derivatives Market? Investopedia. https://www.investopedia.com/ask/answers/052715/how-big-derivatives-market.asp

[9] Adkins, T. (2020) Forward Contracts: The Foundation of All Derivatives. Investopedia.

https://www.investopedia.com/articles/active-trading/102313/why-forward-contract s-are-foundation-all-derivatives.asp

[10] Osayi, V.I., Kasimu, A. and Nkwonta, H.C. (2018) Financial Market Derivatives and the Performance of Deposit Money Banks in Nigeria. International Journal of Economics, Commerce and Management, 6, 382-396.

[11] Osuoha, J.I. (2010) Commodity Trading and Futures. Emmaesth Printing \& Publishing, Lagos, NG.

[12] Osuaha, J.I. (2013) Transforming Nigeria Economy through the Use of Derivatives. Advances in Applied Economics and Finance, 4, 668-677.

[13] Vrolijk, C. (1997) Derivatives Effect on Monetary Policy Transmission. International Monetary Fund, Working Paper 2009, 2-55.

https://doi.org/10.2139/ssrn.882661 